\title{
Interferon- $\beta$ sensitizes human malignant melanoma cells to temozolomide-induced apoptosis and autophagy
}

\author{
KOTARO MAKITA ${ }^{1}$, HIROYUKI HARA ${ }^{2}$, EMIKO SANO $^{3}$, YUTAKA OKAMOTO ${ }^{4}$, YUSHI OCHIAI ${ }^{1}$, \\ TOMONORI HARADA ${ }^{2}$, TAKUYA UEDA ${ }^{3}$, TOMOHIRO NAKAYAMA $^{5}$, \\ SHIN AIZAWA $^{2}$ and ATSUO YOSHINO ${ }^{1}$ \\ ${ }^{1}$ Division of Neurosurgery, Department of Neurological Surgery; ${ }^{2}$ Division of Anatomical Science, \\ Department of Functional Morphology, Nihon University School of Medicine, Tokyo 173-8610; \\ ${ }^{3}$ Department of Computational Biology and Medical Sciences, Graduate School of Frontier Sciences, \\ The University of Tokyo, Tokyo 277-8562; ${ }^{4}$ Japan Agency for Medical Research and Development, Tokyo 100-0004; \\ ${ }^{5}$ Division of Companion Diagnostics, Department of Pathology and Microbiology, \\ Nihon University of School of Medicine, Tokyo 173-8610, Japan
}

Received March 3, 2018; Accepted January 25, 2019

DOI: $10.3892 /$ ijo.2019.4743

\begin{abstract}
Malignant melanoma is a highly aggressive skin cancer that is highly resistant to chemotherapy. Adjuvant therapy is administered to patients with melanoma that possess no microscopic metastases or have a high risk of developing microscopic metastases. Methylating agents, including dacarbazine (DTIC) and temozolomide (TMZ), pegylated interferon (IFN)- $\alpha 2 b$ and interleukin-2 have been approved for adjuvant immuno-chemotherapy; however, unsatisfactory results have been reported following the administration of methylating agents. IFN- $\beta$ has been considered to be a signaling molecule with an important therapeutic potential in cancer. The aim of the present study was to elucidate whether antitumor effects could be augmented by the combination of TMZ and IFN- $\beta$ in malignant melanoma. We evaluated the efficacy of TMZ and IFN- $\beta$ by comparing $\mathrm{O}^{6}$-methylguanine-DNA transferase (MGMT)-proficient and -deficient cells, as MGMT has been reported to be associated with the resistance to methylating agents. Cell viability was determined by counting living cells with a Coulter counter, and apoptosis was analyzed by dual staining with Annexin V Alexa Fluor ${ }^{\circledR} 488$ and propidium iodide. The expression of proteins involved in the cell cycle, apoptosis and autophagy was evaluated by western blot analysis. The combined treatment with TMZ and IFN- $\beta$ suppressed cell proliferation and induced cell cycle arrest. We also demonstrated that a
\end{abstract}

Correspondence to: Professor Hiroyuki Hara, Division of Anatomical Science, Department of Functional Morphology, Nihon University School of Medicine, 30-1 Oyaguchi-Kamicho, Itabashi-ku, Tokyo 173-8610, Japan

E-mail: hara.hiroyuki@nihon-u.ac.jp

Key words: malignant melanoma, temozolomide, human interferon- $\beta$, MGMT, apoptosis, autophagy combination of TMZ and IFN- $\beta$ enhanced apoptosis and autophagy more efficiently compared with TMZ treatment alone. These findings suggest that antitumor activity may be potentiated by IFN- $\beta$ in combination with TMZ.

\section{Introduction}

Malignant melanoma, which is derived from melanocytes, is a highly aggressive skin cancer. The incidence of malignant melanoma continues to increase worldwide (1). Postoperative adjuvant therapy is important in order to prevent tumor recurrence and metastasis (2). Various modalities, including immunological therapy, chemotherapy and radiation have been investigated as adjuvant therapies; however, the effects of advanced melanoma treatment remain unsatisfactory. Recent advances have demonstrated that immunotherapies using immune checkpoint inhibitors, including anti-cytotoxic T lymphocyte antigen-4 and anti-programmed death-1 antibodies, or molecularly-targeted agents, such as $B R A F$ and $M E K$ inhibitors, can markedly alter the effects of melanoma therapy. Of note, these agents exhibit only a transient benefit in the majority of cases (3-5) and patients suffer from the rapid onset of resistance (6). In addition, the financial cost is considerably high and government finances are restricted. Thus, there is an urgent need for novel agents or the novel application of current agents to overcome this aggressive malignancy (7).

Temozolomide (3-methyl-4-oxo-3,4-dihydro-imidazo $[5,1-d][1,2,3,5]$ tetrazine- 8 -carboxamide; TMZ), is an oral alkylating agent employed for the treatment of metastatic melanoma and malignant glioma (8). TMZ, as compared with dacarbazine (DTIC), is very well tolerated and possesses an advantage in terms of improving the quality of life of patients with metastatic melanoma (9). DTIC and TMZ are the most commonly used drugs as first-line therapy for patients with wild-type $B R A F$ tumors in Europe (10). The effect of TMZ has been hypothesized to be dependent on the tumoral expression of $\mathrm{O}^{6}$-methylguanine-DNA transferase (MGMT), 
and low expression of MGMT has been correlated with a high likelihood of the increased sensitivity to TMZ $(11,12)$. MGMT may be a key determinant of cellular resistance to methylating drugs; however, there is no significant association between MGMT expression and the therapeutic response in melanoma (13-15).

Interferons (IFNs) are cytokines; there are two groups of IFNs: type I (IFN- $\alpha$, IFN- $\beta$, IFN- $\tau$ and IFN- $\omega$ ) and type II $($ IFN- $\gamma$ ) (16). IFN- $\alpha 2 b$ and pegylated IFN- $\alpha 2 b$ have been approved in numerous countries as an adjuvant therapy for malignant melanoma (17). On the other hand, IFN- $\beta$ is known to exhibit pleiotropic biological activities, including antiviral, antiproliferative, antiangiogenetic and immunomodulatory effects (18). IFN- $\beta$ also acts as a drug sensitizer to enhance toxicity against a variety of neoplasias when administered in combination with alkylating agents (19). IFN- $\beta$ exhibits greater growth inhibitory and proapoptotic effects than IFN- $\alpha 2$ (20).

TMZ in combination with IFN- $\alpha 2$ has been investigated in metastatic melanomas (21-25). Treatment with a combination of TMZ and IFN- $\alpha$ can increase the median survival of patients with metastatic melanomas (26); however, a combination treatment with TMZ and IFN- $\beta$ has rarely been investigated in malignant melanomas (15). In the present study, TMZ and IFN- $\beta$ was applied to determine whether this combination can exert an antitumor activity on malignant melanomas.

\section{Materials and methods}

Materials. Natural-type of IFN- $\beta$ (Toray Industries, Tokyo, Japan), TMZ (Tokyo Chemical Industry, Tokyo, Japan) and $\mathrm{O}^{6}$-benzylguanine $\left(\mathrm{O}^{6}\right.$-BG; Abcam, Cambridge, UK) were used for the experiments.

Cell lines. Human malignant melanoma A375, CRL-1579, G361, MeWo and SK-MEL-28 cells were purchased from the American Type Culture Collection (Manassas, VA, USA). Cells were routinely cultured in Dulbecco's modified Eagle's medium (Nissui Pharmaceutical, Tokyo, Japan) supplemented with $10 \%$ fetal bovine serum (Thermo Fisher Scientific, Inc., Waltham, MA, USA) using plastic culture flasks (Corning Inc., Corning, NY, USA) in a humidified incubator at $37^{\circ} \mathrm{C}$ with an atmosphere containing $5 \% \mathrm{CO}_{2}$.

Quantification of MGMT $m R N A$ by reverse transcription-quantitative polymerase chain reaction ( $R T$-qPCR). Quantification of the MGMT gene expression was performed via the RT-qPCR method as described previously (27). Complementary DNA was synthesized from $1 \mu \mathrm{g}$ total RNA isolated from five melanoma cell lines using the RNeasy Mini Kit (Qiagen, Inc., Valencia, CA, USA) with a random primer, 40 units M-MLV reverse transcriptase (both from Invitrogen; Thermo Fisher Scientific, Inc.), 0.5 mM dNTP, 24 units RNase inhibitor (both from Takara Bio, Inc., Otsu, Japan), $10 \mu \mathrm{M}$ DTT (Invitrogen; Thermo Fisher Scientific, Inc.) and 5X RT buffer at $37^{\circ} \mathrm{C}$ for $60 \mathrm{~min}$. The qPCR mixture was prepared using a TaqMan Universal Master Mix (Applied Biosystems; Thermo Fisher Scientific, Inc.), $120 \mathrm{nM}$ of each primer and $2.5 \mu \mathrm{l}$ of each cDNA sample. The primers were as follows: MGMT, forward, 5'-CCT GGC TGA ATG CCT ATT TCC-3' and reverse, 5'-GAT GAG GAT GGG GAC AGG ATT-3'; and
200 nM probe, 5'-CGA GCA GTG GGA GGA GCA ATG AGA-3'. The qPCR conditions were as follows: initial denaturation at $95^{\circ} \mathrm{C}$ for $10 \mathrm{~min}$; denaturation 45 cycles at $95^{\circ} \mathrm{C}$ for $30 \mathrm{sec}$, annealing at $60^{\circ} \mathrm{C}$ for $30 \mathrm{sec}$, elongation at $72^{\circ} \mathrm{C}$ for $30 \mathrm{sec}$; and final extension, $72^{\circ} \mathrm{C}$ for $7 \mathrm{~min}$, using a real-time PCR system (ABI PRISM 7900HT Sequence Detection System; Applied Biosystems; Thermo Fisher Scientific, Inc.) as previously reported (28). Glyceraldehyde-3-phosphatase dehydrogenase $(G A D P H)$ mRNA expression levels were employed as the quantitative internal control. Standard curves for $M G M T$ and $G A D P H$ mRNA were generated using 10-fold serially diluted standard plasmid clones (pCR2.1-TOPO TA Vector; Thermo Fisher Scientific, Inc.) containing MGMT or GAPDH PCR products as templates as previously reported $(28,29)$. The amount of each mRNA expression level was calculated from the relevant standard curve. For precise quantification, the MGMT mRNA expression levels of each cell line was normalized based on expression of GADPH. The expression levels were calculated using the equations by comparing the threshold cycles (30).

Growth inhibitory effect. The growth inhibition of malignant melanoma cells by TMZ alone, or a combination of TMZ and IFN- $\beta$ was evaluated by counting the number of cells as previously reported (27). Each well was seeded with $1 \times 10^{4}$ cells in 24 -well plates and cultured for $24 \mathrm{~h}$ at $37^{\circ} \mathrm{C}$. The cells were incubated with fresh medium containing $0.1-1,000 \mu \mathrm{M}$ of $\mathrm{TMZ}$, or medium containing a combination of $0.1,1,10,100$ or $1,000 \mu \mathrm{M}$ of TMZ and $10 \mathrm{IU} / \mathrm{ml}$ of IFN- $\beta$; the cells were cultured for $72 \mathrm{~h}$ at $37^{\circ} \mathrm{C}$. The latter incubation condition (10 IU/ml of IFN- $\beta$ ) was selected as this condition represents a clinically relevant concentration of $\operatorname{IFN}-\beta(31,32)$. For the depletion of the MGMT activity, $10 \mu \mathrm{M}$ of $\mathrm{O}^{6}-\mathrm{BG}$ was added to the cells at $1 \mathrm{~h}$ prior to drug treatment (15). The cells were trypsinized at room temperature for $5 \mathrm{~min}$ with $0.25 \%$ Trypsin-EDTA solution (Invitrogen; Thermo Fisher Scientific, Inc.) and counted using a ZI Coulter Counter ${ }^{\circledR}$ (Beckman Coulter, Inc., Brea, CA, USA). The experiments were repeated at least four times at each concentration.

Cell cycle distribution analysis. The cells were plated at $2 \times 10^{5}$ cells in a 6 -well plate and incubated for $24 \mathrm{~h}$ until attachment to the plate was observed. Following drug treatment, the cells were harvested using a trypsin-EDTA solution at 8 and $24 \mathrm{~h}$, and fixed in ice-cold $70 \%$ ethanol overnight. The fixed cells were treated with $0.5 \%$ RNase A (Roche Diagnostics $\mathrm{GmbH}$, Mannheim, Germany) and stained with $1 \mu \mathrm{g} / \mathrm{ml}$ propidium iodide (PI) for $30 \mathrm{~min}$ at room temperature. The fluorescence was measured with a FACSCalibur flow cytometer (BD Biosciences, Franklin Lakes, NJ, USA) at a wavelength of $610 \mathrm{~nm}$ (FL3). The DNA histograms were analyzed using FlowJo software (version 10.2) (FlowJo LLC, Ashland, OR, USA).

Determination of apoptotic cells. Based on the results for the growth inhibitory and $M G M T$ mRNA expression analyses, A375 and CRL-1579 cells were employed in the further experiments. Apoptosis was detected by dual staining at room temperature for $10 \mathrm{~min}$ with Annexin $\mathrm{V}$ and Propidium Iodide (PI) using Annexin V Alexa Fluor ${ }^{\circledR} 488$ conjugate 
(Thermo Fisher Scientific, Inc.) and PI (Miltenyi Biotec, Inc., Cambridge, CA, USA). A375 and CRL-1579 cells were treated with TMZ alone, or with a combination of TMZ and IFN- $\beta$ for 24,66 and $72 \mathrm{~h}$ at room temperature; adherent and floating cells were then harvested and washed with cold PBS(-) and re-suspended in $1 \mathrm{X}$ binding buffer (Wako Pure Chemical Industries, Ltd., Osaka, Japan). Cells $\left(1 \times 10^{6}\right)$ were treated with $5 \mu \mathrm{l}$ of Annexin V Alexa Fluor 488 conjugate and $10 \mu \mathrm{l}$ of PI solution, and immediately analyzed by flow cytometry according to the manufacturer's protocols. Flow cytometry was performed with a FACSCalibur flow cytometer and apoptosis was analyzed using Flowjo software.

Western blot analysis. Soluble protein lysates of subconfluent melanoma cells were obtained using radioimmunoprecipitation buffer (Wako Pure Chemical Industries, Ltd.) containing protease inhibitors (Complete Mini, EDTA-free; Roche Diagnostics $\mathrm{GmbH}$ ) for $20 \mathrm{~min}$ on ice. Following centrifugation at $20,613 \mathrm{x}$ g for $1 \mathrm{~h}$ at $4^{\circ} \mathrm{C}$, the protein content of the separated supernatants was determined by using a Bicinchoninic Acid assay kit (Pierce; Thermo Fisher Scientific, Inc.). The proteins $(50 \mu \mathrm{g})$ were loaded and separated by $12.5 \%$ polyacrylamide gel electrophoresis and then transferred onto nitrocellulose membranes for 30 min at $15 \mathrm{~V}$ with a Bio-Rad Trans Blot ${ }^{\circledR}$ (both from Bio-Rad Laboratries, Inc., Hercules, CA, USA). The membrane was treated with blocking buffer $(1 \%$ skimmed milk) for $1 \mathrm{~h}$ at room temperature, and subsequently incubated with primary antibodies in fresh blocking buffer for $24 \mathrm{~h}$ at $4^{\circ} \mathrm{C}$. Following rinsing the membrane with washing buffer (PBS/0.05\% Tween-20), the membranes were incubated with a secondary antibody conjugated with horseradish peroxidase (HRP) for $1 \mathrm{~h}$ at $37^{\circ} \mathrm{C}$. The primary antibodies employed were all specific anti-mouse monoclonal antibodies: Anti-Fas (1:500; Santa Cruz Biotechnology, Inc., Dallas, TX, USA), anti-caspase-3 (1:500), anti-caspase-8 (1:1,000), anti-caspase-9 $(1: 1,000)$ (both from Cell Signaling Technology, Inc., Danvers, MA, USA), anti-p53 (1:500), anti-phosphorylated (p)-p53 (1:500), anti-p21 (1:500), anti-B-cell lymphoma 2-associated X protein (Bax; 1:500) (all from Santa Cruz Biotechnology, Inc.), anti-microtubule-associated protein light-chain 3 (LC3) antibody (1:1,000), anti-autophagy regulated gene 5/12 complex (Atg5/Atg12 complex) antibody (1:1,000) (both from Medical \& Biological Laboratories Co., Ltd., Aichi, Japan) and $\beta$-actin (1:2,000; Wako Pure Chemical Industries, Ltd.). The secondary antibody was an HRP-conjugated anti-mouse IgG (Sigma-Aldrich; Darmstadt, Germany) for $1 \mathrm{~h}$ at room temperature. The transferred membrane was washed three times with washing buffer and visualized using LAS-4000 (GE Healthcare, Chicago, IL, USA) following treatment with ECL Prime Western Blotting Detection Reagent according to the manufacturer's protocols (GE Healthcare).

Statistical analysis. All studies were repeated 2-3 times. One-way analysis of variance conducted indicated demonstrated a significant difference between the group and the Tukey-Kramer test was used for multiple comparisons. Data were expressed as the means \pm standard error. $\mathrm{P}<0.05$ was considered to indicate a statistically significant difference. Data analyses were performed using SPSS Statistics version 21.0 (IBM Corporation, Armonk, NY, USA).

\section{Results}

Quantitative MGMT mRNA expression of melanoma cell lines. An important mechanism of resistance to methylating agents, including DTIC and TMZ is DNA repair mediated by the damage-reversal suicide enzyme, MGMT (33). The absolute values for MGMT mRNA in A375, G361, MeWo and SK-MEL-28 were $9.8 \times 10^{3}$ copies $/ \mu \mathrm{g}$ RNA, $7.3 \times 10^{3}$ copies $/ \mu \mathrm{g}$ RNA, $1.5 \times 10^{4}$ copies $/ \mu \mathrm{g}$ RNA and $7.8 \times 10^{3}$ copies $/ \mu \mathrm{g}$ RNA, respectively. In contrast, such expression was not detected in CRL-1579 (data not shown). These findings indicated that the A375, G361, MeWo, and SK-MEL-28 cell lines expressed MGMT, whereas the CRL-1579 cell line did not.

Antitumor efficacy of TMZ, and the combination of TMZ and $I F N-\beta$. To assess the anti-tumor effects of drug treatments, we treated the 5 melanoma cell lines with $0-1,000 \mu \mathrm{M}$ of TMZ alone, or with $0-1,000 \mu \mathrm{M}$ of TMZ plus $10 \mathrm{IU} / \mathrm{ml}$ of IFN- $\beta$; cells were cultured for $72 \mathrm{~h}$. The growth of all 5 cell lines was inhibited by TMZ alone, and with a combination of TMZ and IFN- $\beta$; however, the sensitivity of each of the cell lines varied. The cell growth inhibitory effect of TMZ combined with IFN- $\beta$, compared with TMZ alone, exhibited a dose-dependent pattern, particularly in A375 and CRL-1579 cells (Fig. 1).

Growth inhibitory effects. The concentration of TMZ applied was set at $10 \mu \mathrm{M}$, as this level of TMZ demonstrated growth inhibition in not only MGMT-proficient cells, but also MGMT-deficient cells (Fig. 2). Additionally, this condition represents a clinically applicable dose of TMZ. MGMT is a key determinant of cellular resistance to methylating agents, such as DTIC and TMZ (27). Based on the aforementioned results for the quantification of $M G M T$ mRNA expression and anti-proliferative efficacy, A375 and CRL-1579 cell lines were selected for further experiments.

$\mathrm{O}^{6}$-BG is a modulating agent that induces the inactivation and depletion of MGMT, which is the DNA repair protein, by serving as a substrate and transferring its benzyl group to the active site of MGMT (34). To examine whether the expression of MGMT is responsible for the efficacy of growth inhibition, experiments with A375 and CRL-1579 cells were performed under the specific MGMT inhibitor $\mathrm{O}^{6}$-BG pretreatment conditions for the depletion of residual MGMT activity. In A375 cells, addition of $\mathrm{O}^{6}-\mathrm{BG}$ prior to TMZ treatment significantly induced growth inhibition of the melanoma cells compared with TMZ treatment alone. Furthermore, inactivation of MGMT via $\mathrm{O}^{6}$-BG significantly sensitized A375 cells to combined treatment with TMZ and IFN- $\beta$ compared with combined treatment alone. These findings indicated that $\mathrm{O}^{6}-\mathrm{BG}$ potentiated the anti-proliferative effects of TMZ and that IFN- $\beta$ induced by notable sensitization to TMZ when MGMT was depleted with the specific MGMT inhibitor $\mathrm{O}^{6}$-BG in A375 cells. Conversely, in CRL-1579 cells, there was no significant difference in the growth inhibitory effects between TMZ alone, and combined treatment of TMZ and $\mathrm{O}^{6}-\mathrm{BG}$; however, the addition of IFN- $\beta$ led to significantly decreased cell viability under pretreatment with $\mathrm{O}^{6}$-BG compared with combination treatment of CRL-1579 cells (Fig. 3). 

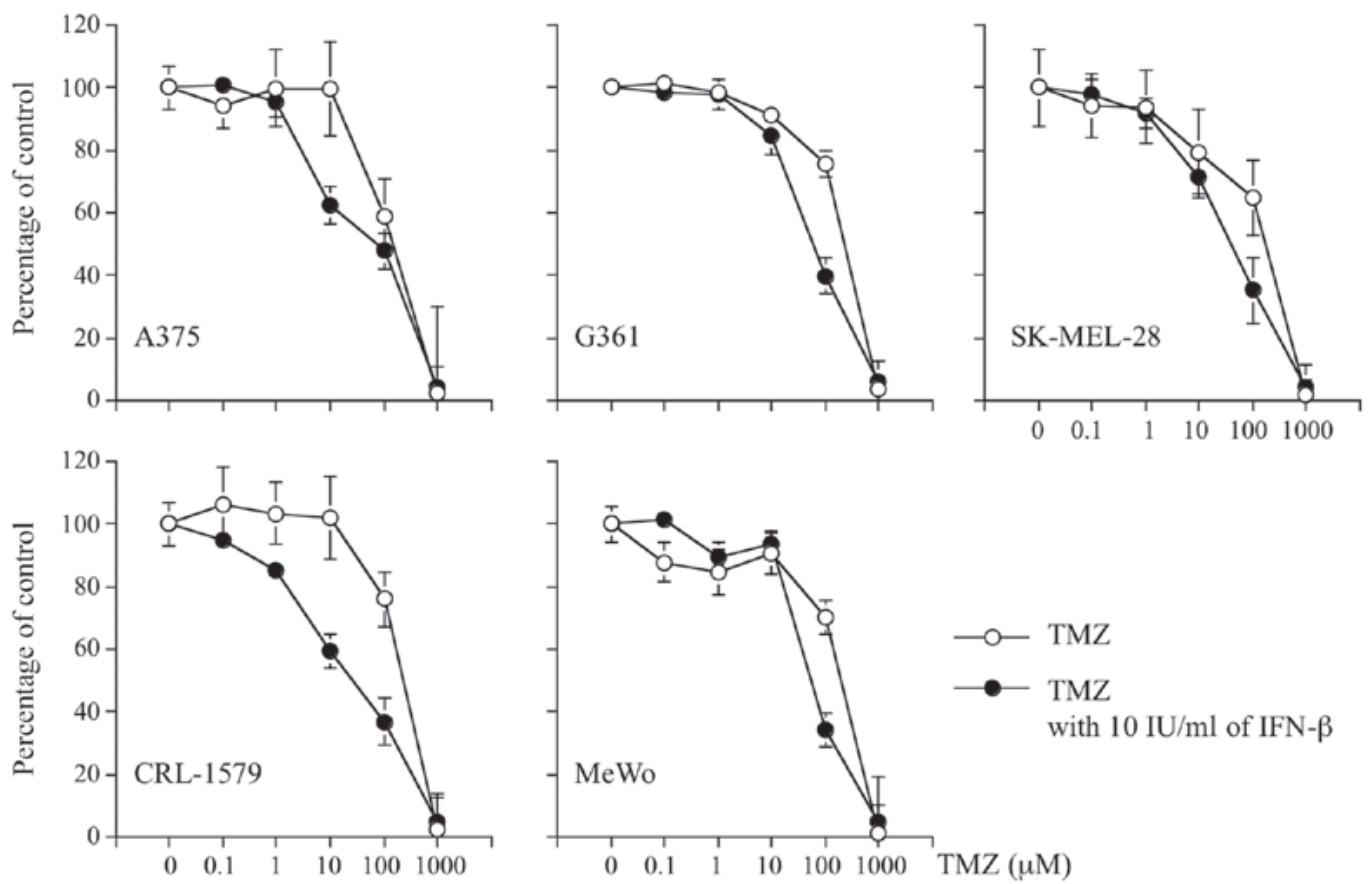

Figure 1. Antiproliferative effects of TMZ and IFN- $\beta$ on malignant melanoma cell lines. TMZ exerted a cell growth inhibitory effect in all cell lines. IFN- $\beta$ enhanced the effects of TMZ, particularly in A375 and CRL-1579 cells. TMZ, temozolomide.
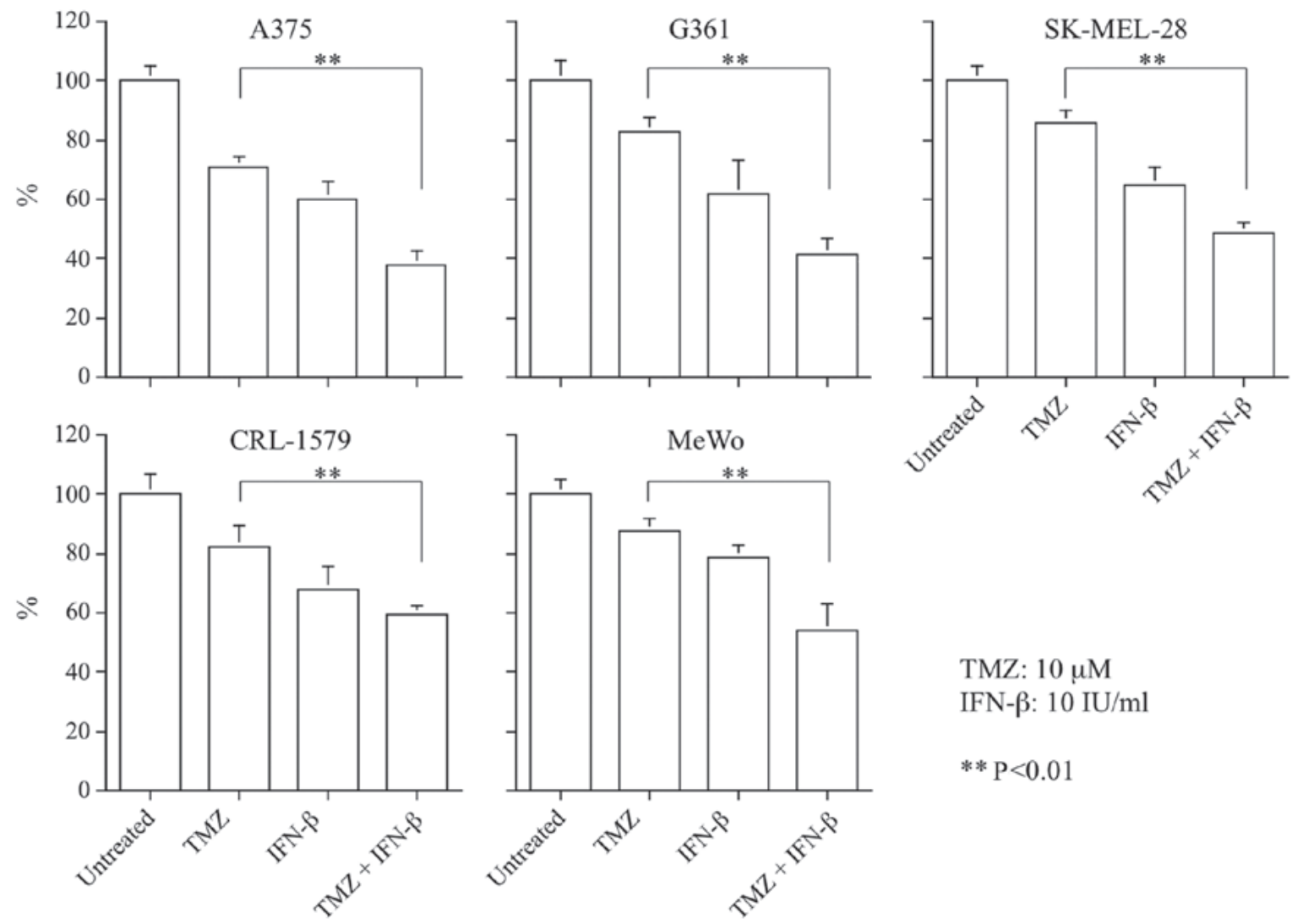

TMZ: $10 \mu \mathrm{M}$

IFN- $\beta$ : $10 \mathrm{IU} / \mathrm{ml}$

$* * \mathrm{P}<0.01$

Figure 2. Effects of IFN- $\beta$ on TMZ-induced growth inhibition. Each well was seeded with $1 \times 10^{4}$ cells in 24 -well plates and cultured for 72 h. A375 and CRL-1579 cells exhibited a significant suppression of cell proliferation following combination treatment. Data are presented as the mean \pm standard error. ${ }^{* * *} \mathrm{P}<0.05$ vs. IFN- $\beta$, interferon- $\beta$; TMZ, temozolomide.

Cell cycle analysis distribution. We performed DNA flow cytometry analysis to investigate whether cell cycle arrest could be induced in malignant melanoma cells by TMZ alone, and with a combination of TMZ and IFN- $\beta$. DNA histograms and the proportions of each cell cycle phase are presented in Fig. 4. We obtained equivalent results from repeating the analyses in 

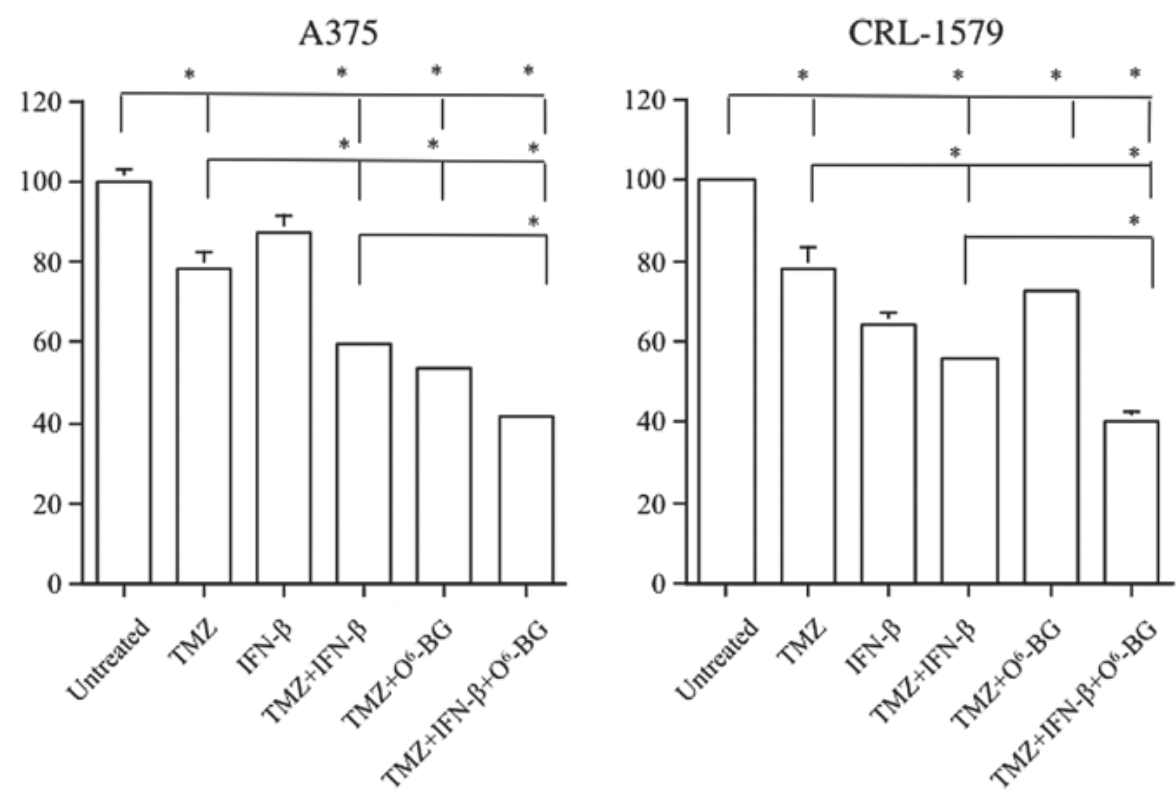

Figure 3. Effects of $\mathrm{O}^{6}-\mathrm{BG}$. When pretreated with $\mathrm{O}^{6}$-BG, IFN- $\beta$ elicited significant sensitization to TMZ in A375 cells. In CRL-1579 cells, which are MGMT deficient cells, combined treatment TMZ and $\mathrm{O}^{6}$-BG in addition to IFN- $\beta$ led to decreased cell viability. This suggests that IFN- $\beta$ increased the sensitization effects of TMZ. Data are presented as the mean \pm standard error. " $\mathrm{P}<0.01$. IFN- $\beta$, interferon- $\beta$; $\mathrm{O}^{6}$-benzylguanine; TMZ, temozolomide.

triplicate; however statistical significance was not observed. In A375 cells, TMZ alone and combination treatment notably increased the number of cells in $\mathrm{G}_{0} / \mathrm{G}_{1}$ phase and decreased the abundance of $\mathrm{G}_{2} / \mathrm{M}$ phase cells at $8 \mathrm{~h}$. Following treatment for $24 \mathrm{~h}$, a combination of TMZ and IFN- $\beta$ increased the population of $S$ and the $G_{2} / M$ phase cells compared with the untreated control. In CRL-1579 cells, TMZ alone and combination treatment increased the cell population in $G_{0} / G_{1}$ phase and decreased that in $\mathrm{G}_{2} / \mathrm{M}$ phase at $8 \mathrm{~h}$. Following treatment for $24 \mathrm{~h}$, a combination of TMZ and IFN- $\beta$ increased the abundance of cells in $\mathrm{G}_{2} / \mathrm{M}$ and $\mathrm{S}$ phase. These findings indicated that TMZ treatment, and a combination of TMZ and IFN- $\beta$ could induce $\mathrm{G}_{0} / \mathrm{G}_{1}$ arrest in melanoma cell lines at $8 \mathrm{~h}$; however, the combined treatment induced $\mathrm{G}_{2} / \mathrm{M}$ arrest in a pattern which differed from that of TMZ alone, particularly in CRL-1579 cells.

Western blot analysis of cell cycle-associated proteins. We hypothesized that $\mathrm{TMZ}$-induced $\mathrm{G}_{0} / \mathrm{G}_{1}$ arrest and combined-treatment-induced $\mathrm{G}_{2} / \mathrm{M}$ arrest in melanoma cells were associated with alterations in the expression of proteins that serve a key role in cell cycle regulation. p53 and p21 have important roles in cellular growth. Thus, we analyzed protein expression associated with the cell cycle mediated by p53 using western blot analysis (Fig. 5). In A375 cells, the expression levels of p53, and p-p53 were increased after $4 \mathrm{~h}$ and were further upregulated after $24 \mathrm{~h}$ following treatment with TMZ alone. The p21 expression levels were increased after 8-48 h. Following combined treatment with TMZ and IFN- $\beta$, the expression levels of p53,p-p53 and p21 were increased after 4-24 h. Similar results were obtained for CRL-1579 cells; however, p53, p-p53, and p21 were notably induced in CRL-1579 cells than in A375 cells following combined treatment with TMZ and IFN- $\beta$ at 4 and $8 \mathrm{~h}$. p21 was observed to show maximum expression after 4 or $8 \mathrm{~h}$.

Activation of apoptosis in melanoma cells induced by TMZ alone, and a combination of TMZ and IFN- $\beta$. The induction of apoptosis by TMZ and IFN- $\beta$ in human melanoma cells was examined by Annexin V/PI double staining and measured using flow cytometry. A375 and CRL-1579 cells were treated with TMZ alone, IFN- $\beta$ alone, or a combination of TMZ and IFN- $\beta$. A375 cells treated with TMZ alone for $72 \mathrm{~h}$ exhibited a $14.5 \%$ increase in Annexin V/PI staining. Following treatment with a combination of TMZ and IFN- $\beta$ for $72 \mathrm{~h}$, the staining intensity increased to $38.7 \%$ (Fig. 6). Conversely, CRL-1579 cells pretreated with TMZ alone for $72 \mathrm{~h}$ exhibited a $27.5 \%$ increase in Annexin V/PI positivity. Following treatment with a combination of TMZ and IFN- $\beta$ for $72 \mathrm{~h}, 56.3 \%$ of the cell were positively stained (Fig. 6).

Protein expression of apoptosis-associated protein is induced by TMZ alone or in combination with IFN- $\beta$. We assessed several apoptosis-associated proteins by western blot analysis in order to examine the mechanisms underlying the anti-apoptotic effect of TMZ and IFN- $\beta$. The intrinsic mitochondrial pathway associated with apoptosis was analyzed, and the extrinsic apoptotic pathway mediated by Fas was also investigated. In melanoma cells treated with TMZ alone, the expression levels of p53 and p-p53 were activated and the levels of Bax, and caspases- 9 and -3 were also increased (Fig. 7A and B). In cells treated with a combination of TMZ and IFN- $\beta$, the findings were similar to those for the cells treated with TMZ alone; however, the duration of activation following treatment with TMZ and IFN- $\beta$ appeared to be earlier compared with TMZ alone. Conversely, the expression of caspases- 8 and -3 in melanoma cells treated with a combination of TMZ and IFN- $\beta$ were upregulated compared with in melanoma cells exposed to TMZ alone after $4 \mathrm{~h}$. This suggests activation of the extrinsic apoptoic pathway mediated by caspase-8 (Fig. 7A and B). Based on these results, IFN- $\beta$ may synergize with TMZ and the combination treatment may potentiate cell death via the intrinsic mitochondrial and the extrinsic signaling pathways. 
A375

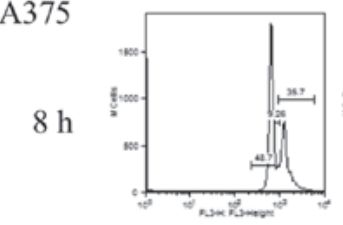

$24 \mathrm{~h}$
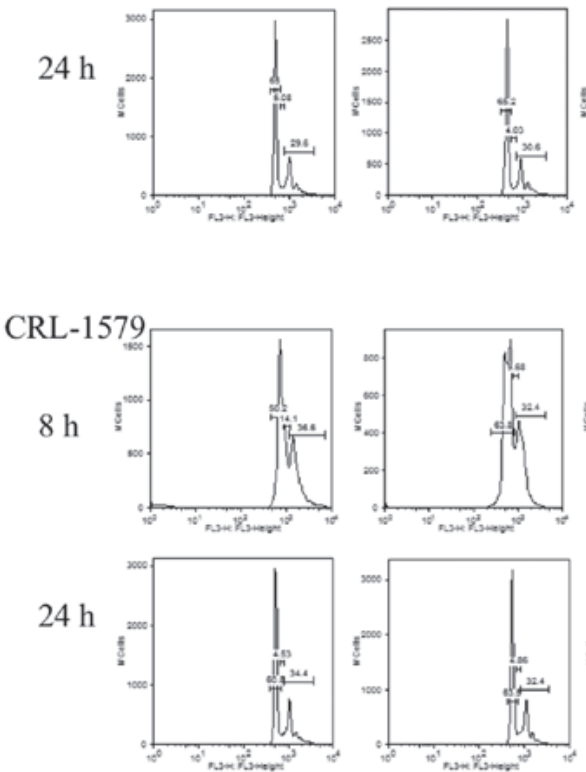

Untreated
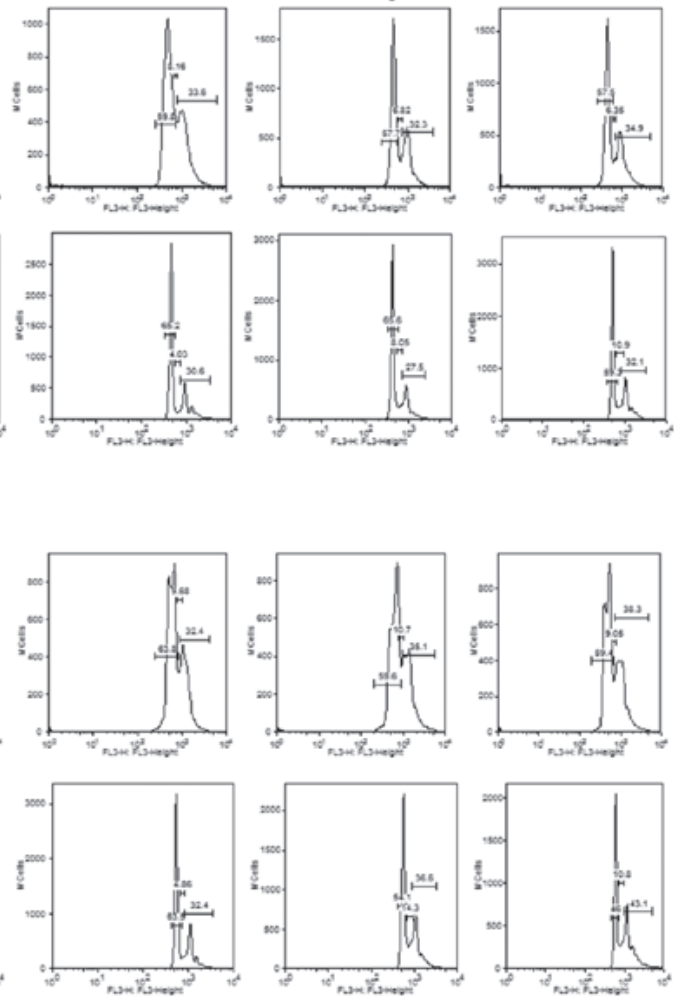

TMZ

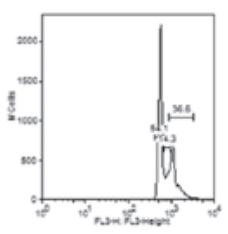

IFN- $\beta$

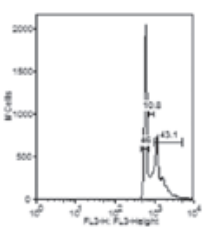

$\mathrm{TMZ}+\mathrm{IFN}-\beta$
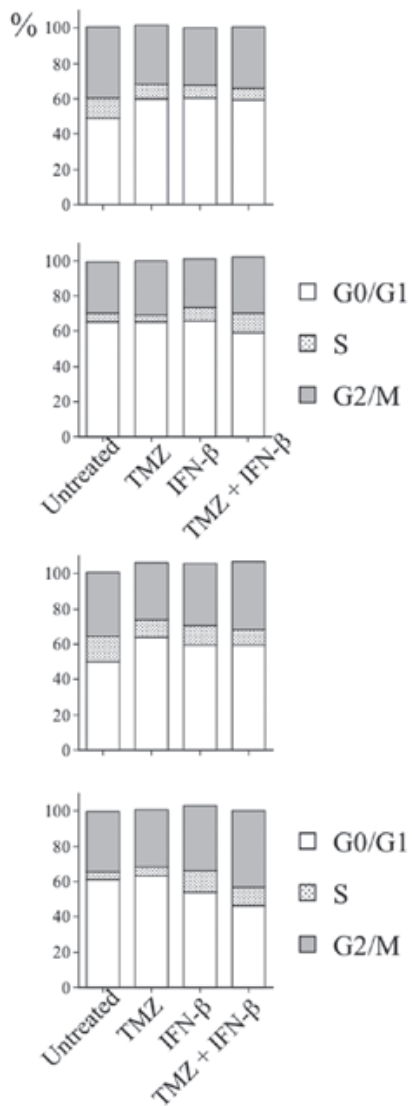

Figure 4. Cell cycle distribution of A375 and CRL-1579 cells treated with TMZ alone, IFN- $\beta$ alone, of a combination of TMZ and IFN- $\beta$ for 8 or 24 h Untreated cells without TMZ alone, IFN- $\beta$ alone or a combination of TMZ and IFN- $\beta$ served as the control. The cells were plated at $2 \times 10^{5}$ cells in a 6 -well plate. The fluorescence-activated cell sorting data demonstrated an increase of cells in the $\mathrm{G}_{0} / \mathrm{G}_{1}$ phase following the combination treatment compared with untreated cells at $8 \mathrm{~h}$ however, the number of $\mathrm{G}_{2} / \mathrm{M}$ cells increased at 24 following combination treatment, indicating that the antitumor efficacy of the combination treatment resulted from the accumulation of cells in the $\mathrm{G}_{2} / \mathrm{M}$ phase. IFN- $\beta$, interferon- $\beta$; $\mathrm{O}^{6}$-benzylguanine; TMZ, temozolomide.

A375

TMZ

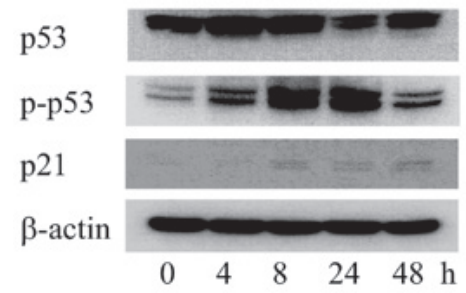

TMZ

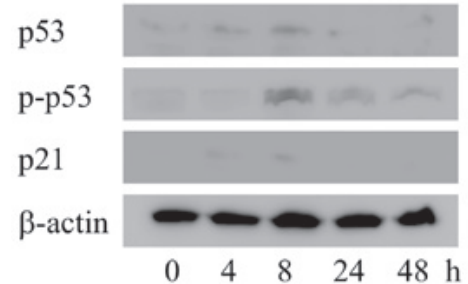

IFN- $\beta$

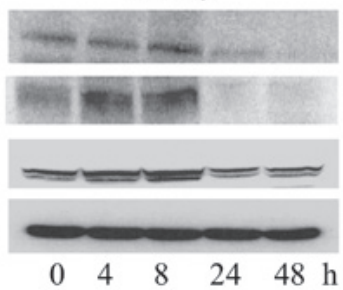

CRL-1579

IFN- $\beta$

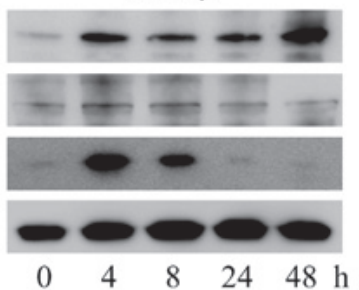

TMZ+IFN- $\beta$

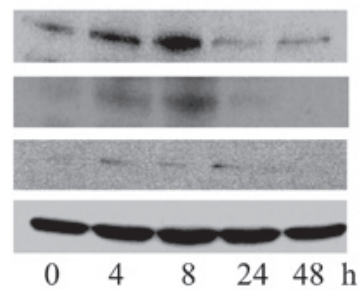

TMZ+IFN- $\beta$

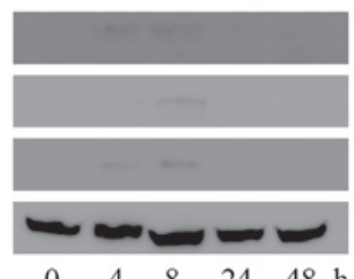

Figure 5. Western blot analysis of proteins associated with the cell cycle. p53, p-p53, and p21 were modulated in response to TMZ alone, IFN- $\beta$ alone, or combind treatment of TMZ and IFN- $\beta$ in A375 and CRL-1579 cells. The protein expressions increased after $4 \mathrm{~h}$. IFN- $\beta$, interferon- $\beta$; TMZ, temozolomide.

Protein expression associated with autophagy is induced by TMZ alone or in combination with IFN- $\beta$. We examined whether TMZ alone or in combination with IFN- $\beta$ can induce autophagy in melanoma cells. The expression levels of LC3 

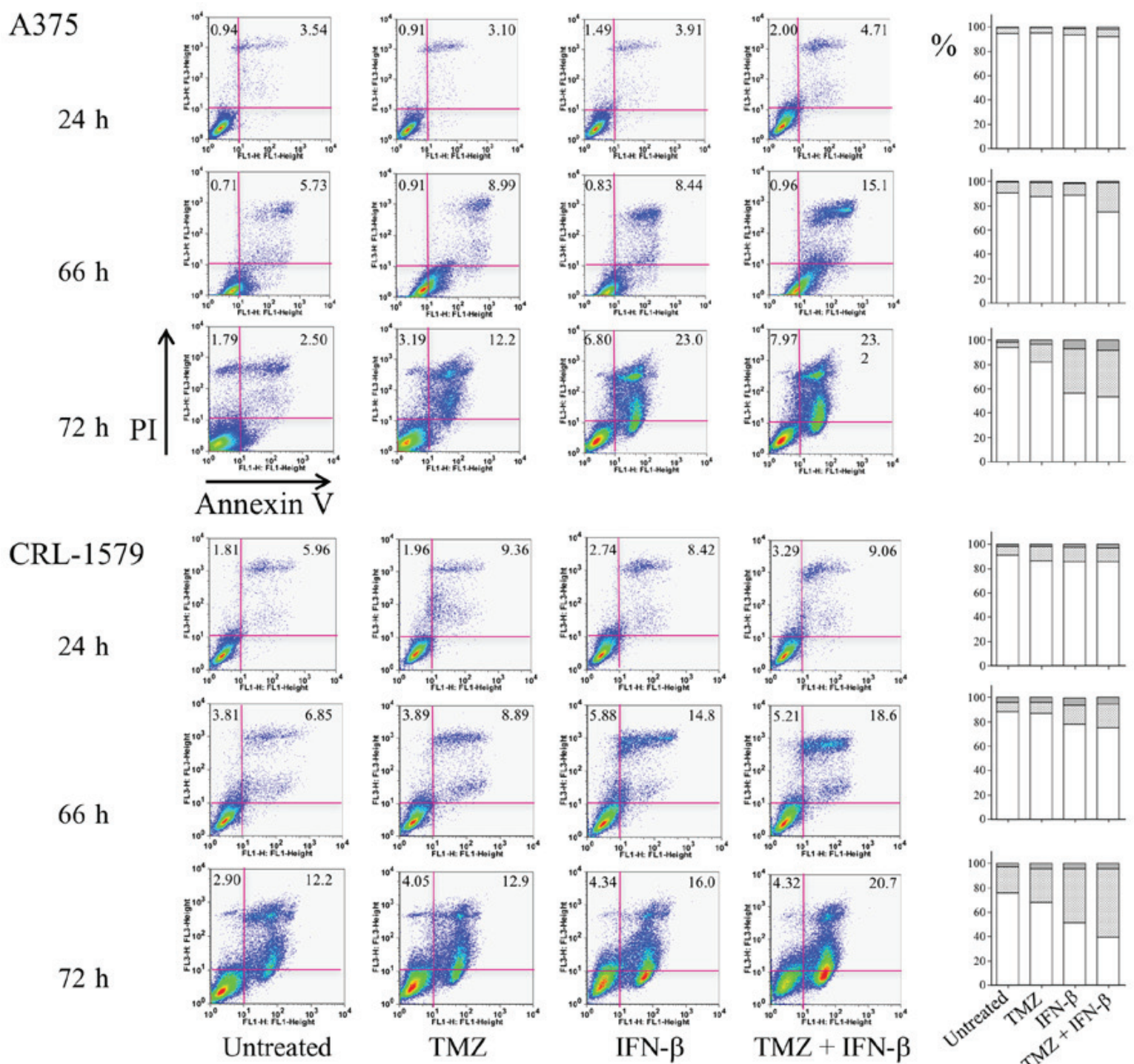

$\square$ Viable

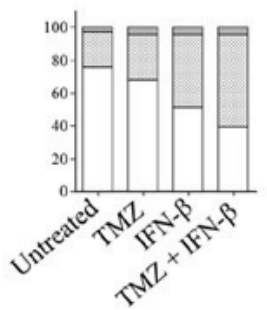

圆 Apoptotic

$\square$ Dead

Figure 6. IFN- $\beta$ induced the apoptosis of A375 and CRL-1579 cells. Combined treatment induced increases in Annexin V- and Annexin V/PI-staining of A375 and CRL-1579 cells. $1 \times 10^{6}$ cells were treated with $5 \mu 1$ of Annexin V Alexa Fluor ${ }^{\circledR} 488$ conjugate and $10 \mu 1$ of PI solution. The percentages of Annexin V-positive Annexin V/PI-positive cells were presented at in the bottom right and top right quandrants, respectively. IFN- $\beta$, interferon- $\beta$; PI, propidium iodide; TMZ, temozolomide.

protein and Atg5/Atg12 complex proteins were elevated following TMZ treatment at $4 \mathrm{~h}$ in A375 and CRL-1579 cells. These protein levels were clearly increased and activated relatively soon after treatment with TMZ and IFN- $\beta$ in A375 and CRL-1579 cells (Fig. 8). These findings indicated that the induction of autophagy by TMZ and IFN- $\beta$ may promote this process in melanoma cells.

\section{Discussion}

In the present study, we found that the antiproliferative properties in melanoma cells may be ascribed to inhibition of cell growth, and the induction of apoptosis and autophagy.

The effects of methylating agents have been hypothesized to be dependent on tumoral expression of MGMT. Overexpression of MGMT protects against alkylation-induced cell death; low expression of MGMT is correlated with a high likelihood of a response to methylating agents $(12,35)$. Melanomas tend to express low levels of MGMT $(36,37)$, which could explain why melanomas respond to methylating drugs, including DTIC and TMZ, but not to other anticancer drugs. MGMT can determine the clinical outcome in melanoma therapy with methylating drugs; however, conflicting data have been reported (33). No significant association was observed between MGMT immunoexpression and the response to TMZ $(13,14)$. The present study demonstrated that A375 cells were more sensitized to TMZ than CRL-1579 cells following depletion of MGMT with $\mathrm{O}^{6}$-BG. In addition, these two cell lines exhibited a notably increased sensitivity to combined treatment with TMZ and IFN- $\beta$ than TMZ alone. These findings were consistent with those reported Roos et al (15), that is, IFN- $\beta$ increased sensitization effects of cells to TMZ, when depleting MGMT with $\mathrm{O}^{6}-\mathrm{BG}$. The addition of IFN- $\beta$ led to decreases in cell viability when depleted with $\mathrm{O}^{6}$-BG; analysis of MGMT-deficient cells suggested that $\mathrm{O}^{6}-\mathrm{BG}$ may have increased cell death sensitivity (38), and that IFN- $\beta$ did not affect MGMT (15).

The $\mathrm{G}_{2} / \mathrm{M}$ checkpoint serves an important role in the action of TMZ in melanomas $(39,40)$. We revealed that IFN- $\beta$ 
A

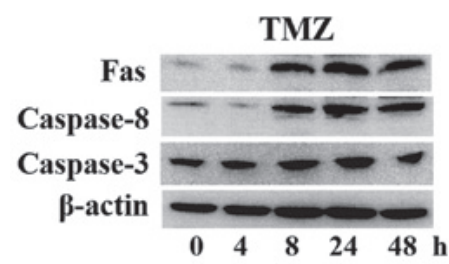

TMZ

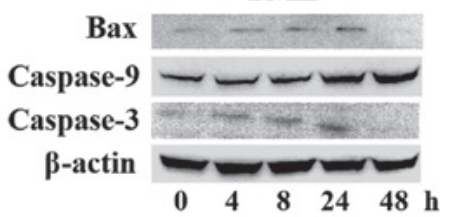

B

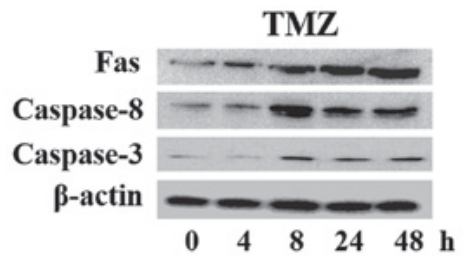

TMZ

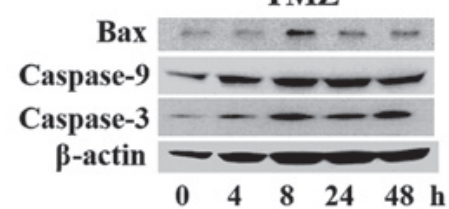

A375

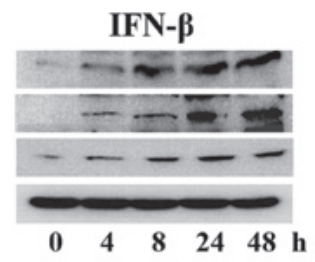

IFN- $\beta$

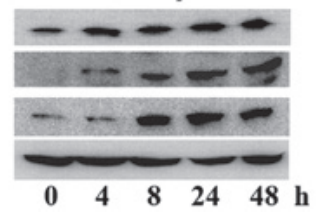

CRL-1579

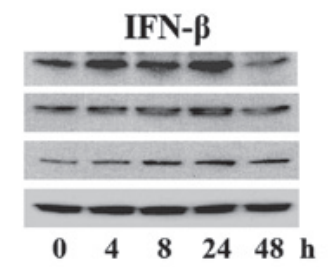

IFN- $\beta$

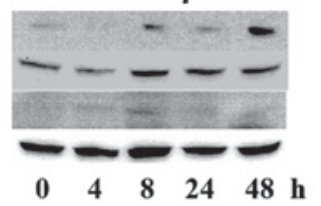

TMZ+IFN- $\beta$

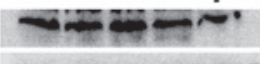

$\rightarrow=0$

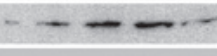

$\begin{array}{llllll}0 & 4 & 8 & 24 & 48 & h\end{array}$

TMZ+IFN- $\beta$

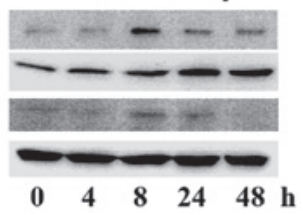

TMZ+IFN- $\beta$

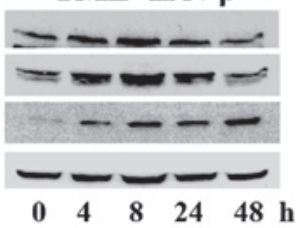

TMZ+IFN- $\beta$

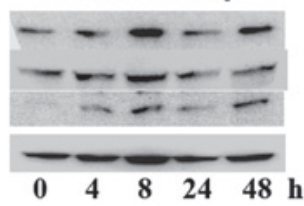

Figure 7. Western blot analysis of proteins associated with apoptosis in A375 and CRL-1579 cells. TMZ treatment activated the intrinsic mitochondrial and the extrinsic signaling pathway in (A) A375 and (B) CRL-1579 cells. In particular, combined treatment with TMZ and IFN- $\beta$ activated the intrinsic mitochondrial and extrinsic signaling pathways. Bax, B-cell lymphoma-2-associated X protein; IFN- $\beta$, interferon- $\beta$; TMZ, temozolomide.

sensitized melanoma cells to TMZ to induce $\mathrm{G}_{2} / \mathrm{M}$ arrest. In addition, combination treatment of TMZ and IFN- $\beta$ was associated with alterations in the expression of proteins that serve a key role in the regulation of the cell cycle.

The biological outcomes of p53 activity include the inhibition of cell cycle progression, senescence, differentiation, acceleration of DNA repair and apoptosis (41). p21 and cyclin-dependent kinase inhibitor 1 are activated by p53 and induces cell cycle arrest in $G_{0} / G_{1}$ phase. In the present study, the expression levels of p21 as investigated by western blot analysis increased following combined treatment of TMZ and IFN- $\beta$ treatment of A375 and CRL-1579 cells. The data suggested that one of the mechanisms underlying the antitumor effects this particular treatment combination is cell cycle arrest in melanoma cells. p53 inhibits cell cycle progression and has been demonstrated to be functionally inactivated in a variety of human cancers (42). IFN- $\alpha / \beta$ signaling affects the $\mathrm{p} 53$ responses in tumor suppression and antiviral defense (43). The sensitization effect of IFN- $\beta$ in TMZ-treated melanoma cells is dependent on p53 (15), in which p21 is directly activated (44). In addition to growth inhibition, $\mathrm{G}_{2} / \mathrm{M}$ cell cycle arrest as a result of p21 activation following treatment with TMZ plus IFN- $\beta$ was observed in the present study. As p21 has been observed to be associated with the induction of apoptosis $(45,46)$, upregulation of p21 in melanoma cells may affect the induction of apoptosis.
IFN- $\beta$ induced apoptosis, which was linked to the activation of Bax gene expression $(47,48)$.

The present study investigated apoptotic cell death via Annexin V/PI staining. There are several distinct processes associated with cell death which include not only apoptosis and necrosis, but also necroptosis, autophagy and ferroptosis (49). In the present study, there appeared to be a discrepancy between the results of growth inhibition and apoptosis analyses. Different methods were conducted and different cell process were investigated; however, an antitumor effect was observed following combination treatment. We also investigated numerous apoptosis-related proteins by western blot analysis. The proportion of Annexin V-positive melanoma cells increased irrespective of the treatment in a time-dependent manner; however, the proportion of apoptotic cells were higher for combination treatment with TMZ and IFN- $\beta$ than TMZ alone in A375 and CRL-1579 cells. Compared with A375 cells, the number of apoptotic cells was notable increased in CRL-1579 cells following combined treatment. IFN- $\beta$ in combination with TMZ led to a high degree of early apoptotic responses, particularly in CRL-1579 cells by flow cytometric analysis. A key regulator of apoptosis is the mitochondrial intrinsic signaling pathway and another is the Fas/cluster of differentiation 95/Apo-1 extrinsic signaling pathway. In the present study, p53 and its downstream effector Bax, were 


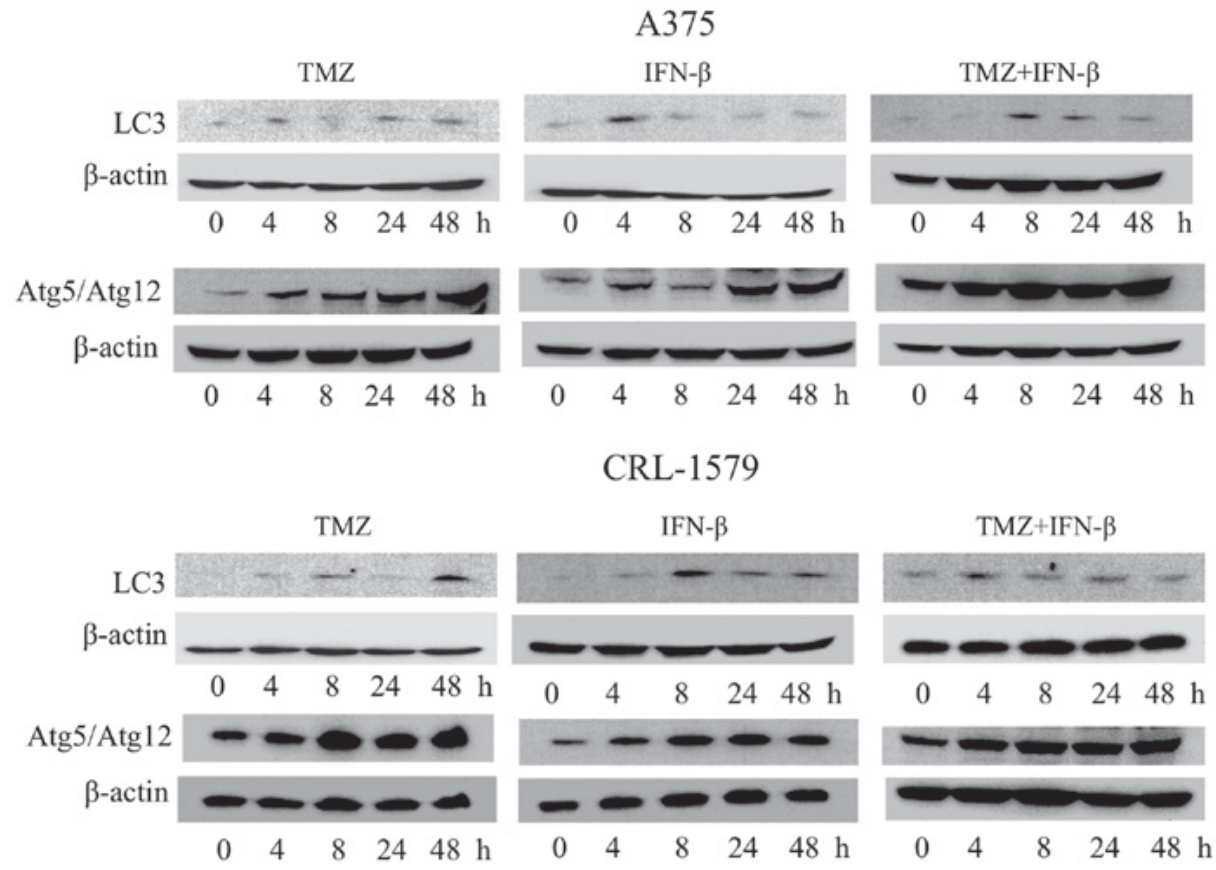

Figure 8. Western blot analysis of proteins associated with autophagy. Expression of the LC3 1 and Atg5/Atg12 complex proteins were notably increased and activated following treatment with TMZ, or the combination of TMZ and IFN- $\beta$ in A375 and CRL-1579 cells. Atg5/Atg12, autophagy regulated gene $5 / 12$ complex; LC, microtubule-associated protein light-chain 3 ; IFN- $\beta$, interferon- $\beta$; TMZ, temozolomide.

upregulated in A375 and CRL-1579 cells treated with TMZ alone. Notable increases in apoptosis were observed following the combined treatment of TMZ + IFN- $\beta$. Regarding caspases, we reported increases in the expression of caspases -9 and -3 . During the investigation of the intrinsic and extrinsic pathways, the expression of caspase-3 differed, that is, the expression of caspase-3 was upregulated in studying the extrinsic and intrinsic pathways following combination treatment of CRL-1579, and that caspase-3 was upregulated in A375 cells. Unknown factors may have affected caspase- 3 or cell variation may be a contributing cause for differing observations; however, the underlying mechanism requires further investigation. Melanomas express numerous extrinsic death receptors, Fas, tumor necrosis factor (TNF) and TNF-related apoptosis-inducing ligand (7). Activation of the apoptotic pathway may occur via Fas-L/FasR and activation of downstream caspase- $8(50,51)$. In the present study, a combination of TMZ and IFN- $\beta$ induced Fas expression and its proximal downstream caspase- 8 expression, thereby activating the Fas/CD95/Apo-1 extrinsic apoptotic signaling pathway. Roos et al (15) have reported that the induction of Fas/CD95/Apo-1 by TMZ and the upregulation of procaspase-8 are required for the sensitization observed during combination therapy.

We demonstrated that malignant melanoma cells undergo apoptosis following the treatments with TMZ and IFN- $\beta$. In addition, the present study revealed that CRL-1579 cells exhibited a higher degree of apoptosis compared with A375 cells, which indicated that alkylation-induced cell death may be largely attributable to apoptosis and $\mathrm{O}^{6}$-methyl-guanine $\left(\mathrm{O}^{6} \mathrm{MeG}\right)$ acted as an inducer in the toxic response of TMZ $(36,52,53)$. The apoptotic process investigated in our study required p53, and $\mathrm{O}^{6} \mathrm{MeG}$ may lead to the apoptosis of A375 and CRL-1579 cells with dependence on $\mathrm{p} 53$. These findings suggested that IFN- $\beta$ may promote the apoptosis induced by TMZ in melanoma cells.
Recent evidence has demonstrated that autophagy can often occur with apoptosis during the process of programmed cell death (30). In the present study, it was observed that TMZ alone and in combination with IFN- $\beta$ induced not only apoptosis, but also autophagy in melanoma cells. Therefore, IFN- $\beta$ may markedly induce autophagy when combined with TMZ. Autophagy was originally designated as a process of protein recycling (54). Autophagosome nucleation is mediated by Belin 1 (Atg6). Subsequently, the Atg5/Atg12 complex and LC3 (Atg8) are required for the elongation of autophagosomes (55). The abundance of LC3-II is increased via the conversion of LC3-I (56). Autophagy serves complex roles in cancer, which can promote or inhibit tumorigenesis (54). Functional crosstalk exists between autophagy and apoptosis (57), and autophagy can occur with apoptosis in the process of programmed cell death (53). Autophagic degradation of active caspase- 8 has been associated with the crosstalk between autophagy and apoptosis (58). IFN- $\beta$ also regulates the adaptive immune response and the innate immune response by inducing $\mathrm{C}-\mathrm{X}-\mathrm{C}$ motif chemokine ligand 10 or Toll-like receptor 3 (59). These processes require further investigation and the effects of IFN-dependent innate immunity in cancer are to be determined in the future.

The results of the present study suggested that the clinical therapeutic efficacy of TMZ may be enhanced by the combined treatment of TMZ and IFN- $\beta$ in malignant melanomas. Combination treatment of TMZ and IFN- $\beta$ suppressed cell proliferation, and enhanced apoptosis and autophagy in melanoma cells. The present study did not investigate the chemoresistance of melanoma cells treated with TMZ and IFN- $\beta$; the underlying mechanism remains unknown. On the contrary, our data demonstrated that one of the possible immunomodulatory effects of IFN- $\beta$ may be that IFN- $\beta$ acts as a sensitizer of malignant melanomas to enhance the toxicity of TMZ. Experiments using TMZ and IFN- $\beta$ were conducted 
in the present study as it has been reported that IFN- $\beta$ exerts notable inhibitory effects on melanoma cells to IFN- $\alpha$ (60-62). Tus, this treatment may be applied in the treatment of melanoma; however, future studies should be conducted.

\section{Acknowledgements}

The authors are grateful to Mr. Hiroyuki Satake and Mr. Nobuo Miyazaki, Toray Industries Inc. (Tokyo, Japan), for their invaluable discussions. The authors would also like to thank Ms. Miyuki Yuda, Division of Anatomical Science, Department of Functional Morphology, Nihon University School of Medicine (Tokyo, Japan), for her excellent technical assistance. Some parts of this study have been included in the Japanese-language thesis for Kotaro Makita's Ph.D. degree at Nihon University School of Medicine (Tokyo, Japan).

\section{Funding}

This work was supported in part by Grants-in-Aid for Scientific Research from the Japan Society for the Promotion of Science (grant no. 16K10772) and in part by the Health Sciences Research Institute, Inc. (Yokohama, Japan) to the Division of Companion Diagnostics, Department of Pathology and Microbiology, Nihon University School of Medicine.

\section{Availability of data and materials}

All data analysed during this study are included in this article.

\section{Authors' contributions}

KM and ES performed the experimental design, most of the experiments and analysis, drafted the manuscript. $\mathrm{HH}$ was involved in the conception and design of the study, analyzed the data and contributed to the writing of the manuscript. YO (Ochiai) and $\mathrm{TH}$ also conducted experiments and analyzed the data. YO (Okamoto), TU, TN and SA supervised the study and proofread the manuscript. AY contributed to the writing of the manuscript. All authors have read and approved the final manuscript.

\section{Ethics approval and consent to participate}

Not applicable.

\section{Patient consent to participate}

Not applicable.

\section{Competing interests}

The authors declare that they have no competing interests.

\section{References}

1. Cancer Facts and Figures 2009. American Cancer Society, Atlanta, 2009

2. Coit DG, Andtbacka R, Anker CJ, Bichakjian CK, Carson WE III, Daud A, Dimaio D, Fleming MD, Guild V, Halpern AC, et al: Melanoma, version 2.2013: featured updates to the NCCN guidelines. J Natl Compr Canc Netw 11: 395-407, 2013.
3. Kainthla R, Kim KB and Falchook GS: Dabrafenib for treatment of BRAF-mutant melanoma. Pharmgenomics Pers Med 7: 21-29, 2013.

4. Jang S and Atkins MB: Which drug, and when, for patients with BRAF-mutant melanoma? Lancet Oncol 14: e60-e69, 2013.

5. Jang S and Atkins MB: Treatment of BRAF-mutant melanoma: The role of vemurafenib and other therapies. Clin Pharmacol Ther 95: 24-31, 2014.

6. Homet B and Ribas A: New drug targets in metastatic melanoma. J Pathol 232: 134-141, 2014.

7. Nihal M, Wu J and Wood GS: Methotrexate inhibits the viability of human melanoma cell lines and enhances Fas/Fas-ligand expression, apoptosis and response to interferon-alpha: Rationale for its use in combination therapy. Arch Biochem Biophys 563: 101-107, 2014.

8. Yoshino A, Tashiro S, Ogino A, Yachi K, Ohta T, Fukushima T, Watanabe T, Katayama Y, Okamoto Y, Sano E, et al: Gene expression profiles predicting the response to IFN- $\beta$ and a combination of temozolomide and IFN- $\beta$ in malignant gliomas. Int J Oncol 39: 529-542, 2011.

9. Li RH, Hou XY, Yang CS, Liu WL, Tang JQ, Liu YQ and Jiang G: Temozolomide for treating malignant melanoma. J Coll Physicians Surg Pak 25: 680-688, 2015.

10. Harries M, Malvehy J, Lebbe C, Heron L, Amelio J, Szabo Z and Schadendorf D: Treatment patterns of advanced malignant melanoma (stage III-IV) - A review of current standards in Europe. Eur J Cancer 60: 179-189, 2016.

11. Losa M, Mazza E, Terreni MR, McCormack A, Gill AJ, Motta M, Cangi MG, Talarico A, Mortini P and Reni M: Salvage therapy with temozolomide in patients with aggressive or metastatic pituitary adenomas: Experience in six cases. Eur J Endocrinol 163: 843-851, 2010.

12. Zuhur SS, Tanik C, Karaman Ö, Velet S, Cil E, Öztürk FY, Özkayalar H, Müslüman AM and Altuntaş Y: MGMT immunoexpression in growth hormone-secreting pituitary adenomas and its correlation with Ki-67 labeling index and cytokeratin distribution pattern. Endocrine 40: 222-227, 2011.

13. Bush ZM, Longtine JA, Cunningham T, Schiff D, Jane JA Jr, Vance ML, Thorner MO, Laws ER Jr and Lopes MB: Temozolomide treatment for aggressive pituitary tumors: Correlation of clinical outcome with $\mathrm{O}(6)$-methylguanine methyltransferase (MGMT) promoter methylation and expression. J Clin Endocrinol Metab 95: E280-E290, 2010.

14. Raverot G, Sturm N, de Fraipont F, Muller M, Salenave S, Caron P, Chabre O, Chanson P, Cortet-Rudelli C, Assaker R, et al: Temozolomide treatment in aggressive pituitary tumors and pituitary carcinomas: A French multicenter experience. J Clin Endocrinol Metab 95: 4592-4599, 2010.

15. Roos WP, Jöst E, Belohlavek C, Nagel G, Fritz G and Kaina B: Intrinsic anticancer drug resistance of malignant melanoma cells is abrogated by IFN- $\beta$ and valproic acid. Cancer Res 71: 4150-4160, 2011

16. Sano E, Tashiro S, Tadakuma H, Takei T, Ueda $\mathrm{T}$ and Tsumoto K: Type 1 IFN inhibits the growth factor deprived apoptosis of cultured human aortic endothelial cells and protects the cells from chemically induced oxidative cytotoxicity. J Cell Biochem 113: 3823-3834, 2012.

17. Herndon TM, Demko SG, Jiang X, He K, Gootenberg JE, Cohen MH, Keegan P and Pazdur R: U.S. food and drug administration of patients with melanoma. Oncologist 17: 1323-1328, 2012.

18. Baron S, Tyring SK, Fleischmann WR Jr, Coppenhaver DH, Niesel DW, Klimpel GR, Stanton GJ and Hughes TK: The interferons. Mechanisms of action and clinical applications. JAMA 266: 1375-1383, 1991.

19. Yoshida J, Kajita Y, Wakabayashi T and Sugita K: Long-term follow-up results of 175 patients with malignant glioma: Importance of radical tumour resection and postoperative adjuvant therapy with interferon, ACNU and radiation. Acta Neurochir (Wien) 127: 55-59, 1994.

20. Chawla-Sarkar M, Leaman DW and Borden EC: Preferential induction of apoptosis by interferon (IFN)-beta compared with IFN-alpha2: Correlation with TRAIL/Apo2L induction in melanoma cell lines. Clin Cancer Res 7: 1821-1831, 2001.

21. García M, del Muro XG, Tres A, Crespo C, Valladares M, López JJ, Rifà J, Pérez X, Filipovich E and Germà-Lluch JR: Phase II multicentre study of temozolomide in combination with interferon alpha- $2 b$ in metastatic malignant melanoma. Melanoma Res 16: 365-370, 2006.

22. Hwu WJ, Panageas KS, Menell JH, Lamb LA, Aird S, Krown SE, Williams LJ, Chapman PB, Livingston PO, Wolchok JD, et al: Phase II study of temozolomide plus pegylated interferon-alpha- $2 \mathrm{~b}$ for metastatic melanoma. Cancer 106: 2445-2451, 2006. 
23. Quirt I, Verma S,Petrella T,Bak K and Charette M: Temozolomide for the treatment of metastatic melanoma: A systematic review. Oncologist 12: 1114-1123, 2007.

24. Guillot B, Khamari A, Cupissol D, Delaunay M, Bedane C, Dreno B, Picot MC and Dereure O: Temozolomide associated with PEG-interferon in patients with metastatic melanoma: A multicenter prospective phase I/II study. Melanoma Res 18: 141-146, 2008.

25. Spieth K, Kaufmann R, Dummer R, Garbe C, Becker JC, Hauschild A, Tilgen W, Ugurel S, Beyeler M, Bröcker EB, et al: Temozolomide plus pegylated interferon alfa- $2 b$ as first-line treatment for stage IV melanoma: A multicenter phase II trial of the Dermatologic Cooperative Oncology Group (DeCOG). Ann Oncol 19: 801-806, 2008

26. Ridolfi R, Romanini A, Sileni VC, Michiara M, Guida M, Biasco G, Poletti P, Amaducci L, Leoni M and Ravaioli A: Temozolomide and interferon-alpha in metastatic melanoma: A phase II study of the Italian Melanoma Intergroup. Melanoma Res 14: 295-299, 2004.

27. Yoshino A, Ogino A, Yachi K, Ohta T, Fukushima T, Watanabe T, Katayama Y, Okamoto Y, Naruse N and Sano E: Effect of IFN-beta on human glioma cell lines with temozolomide resistance. Int J Oncol 35: 139-148, 2009.

28. Tanaka S, Oka H, Fujii K, Watanabe K, Nagao K and Kakimoto A Quantitation of $\mathrm{O}^{6}$-methylguanine-DNA methyltransferase gene messenger RNA in gliomas by means of real-time RT-PCR and clinical response to nitrosoureas. Cell Mol Neurobiol 25 : 1067-1071, 2005

29. Tanaka S, Kobayashi I, Utsuki S, Oka H, Fujii K, Watanabe T, Nagashima $\mathrm{T}$ and Hori T: $\mathrm{O}^{6}$-methylguanine-DNA methyltranspherase gene expression in gliomas by means of real-time quantitative RT-PCR and clinical response to nitrosoureas. Int J Cancer 103: 67-72, 2003.

30. Livak KJ and Schmittgen TD: Analysis of relative gene expression data using real-time quantitative PCR and the 2(-Delta Delta C(T)) method. Methods 25: 402-408, 2001.

31. Ostermann S, Csajka C, Buclin T, Leyvraz S, Lejeune F, Decosterd LA and Stupp R: Plasma and cerebrospinal fluid population pharmacokinetics of temozolomide in malignant glioma patients. Clin Cancer Res 10: 3728-3736, 2004.

32. Higuchi Y and Hashida M: Pharmacokinetics of interferon. Clin All-Round 52: 2499-2505, 2003 (In Japanese).

33. Naumann SC, Roos WP, Jöst E, Belohlavek C, Lennerz V, Schmidt CW, Christmann M and Kaina B: Temozolomide- and fotemustine-induced apoptosis in human malignant melanoma cells: Response related to MGMT, MMR, DSBs, and p53. Br J Cancer 100: 322-333, 2009.

34. Friedman HS, Keir S, Pegg AE, Houghton PJ, Colvin OM, MoschelRC,BignerDDandDolanME: ${ }^{6}$-benzylguanine-mediated enhancement of chemotherapy. Mol Cancer Ther 1: 943-948, 2002

35. Kaina B, Fritz G, Mitra S and Coquerelle T: Transfection and expression of human $\mathrm{O}^{6}$-methylguanine-DNA methyltransferase (MGMT) cDNA in Chinese hamster cells: The role of MGMT in protection against the genotoxic effects of alkylating agents. Carcinogenesis 12: 1857-1867, 1991

36. Chen JM, Zhang YP, Wang C, Sun Y, Fujimoto J and Ikenaga M $\mathrm{O}^{6}$-methylguanine-DNA methyltransferase activity in human tumors. Carcinogenesis 13: 1503-1507, 1992.

37. Kaina B, Ziouta A, Ochs K and Coquerelle T: Chromosomal instability, reproductive cell death and apoptosis induced by $\mathrm{O}^{6}$-methylguanine in $\mathrm{Mex}^{-}, \mathrm{Mex}^{+}$and methylation-tolerant mismatch repair compromised cells: Facts and models. Mutat Res 381: 227-241, 1997.

38. Liu L, Markowitz S and Gerson SL: Mismatch repair mutations override alkyltransferase in conferring resistance to temozolomide but not to 1,3-bis(2-chloroethyl)nitrosourea. Cancer Res 56: 5375-5379, 1996.

39. Hirose Y, Berger MS and Pieper RO: p53 effects both the duration of $\mathrm{G}_{2} / \mathrm{M}$ arrest and the fate of temozolomide-treated human glioblastoma cells. Cancer Res 61: 1957-1963, 2001

40. Beaumont KA, Hill DS, Daignault SM, Lui GYL, Sharp DM, Gabrielli B, Weninger W and Haass NK: Cell cycle phase-specific drug resistance as an escape mechanism of melanoma cells. J Invest Dermatol 136: 1479-1489, 2016.

41. Natsume A, Ishii D, Wakabayashi T, Tsuno T, Hatano $H$, Mizuno $M$ and Yoshida J: IFN-beta down-regulates the expression of DNA repair gene MGMT and sensitizes resistant glioma cells to temozolomide. Cancer Res 65: 7573-7579, 2005.
42. Levine AJ: $\mathrm{p} 53$, the cellular gatekeeper for growth and division. Cell 88: 323-331, 1997.

43. Takaoka A, Hayakawa S, Yanai H, Stoiber D, Negishi H, Kikuchi H, Sasaki S, Imai K, Shibue T, Honda K, et al: Integration of interferon-alpha/beta signalling to p53 responses in tumour suppression and antiviral defence. Nature 424: 516-523, 2003

44. Zhang X, Fang P, Zhao Z, Ding X, Xie F, Wang Y and Li C: Antitumorigenic effect of damnacanthal on melanoma cell viability through $\mathrm{p} 53$ and $\mathrm{NF}-\mathrm{\kappa B} /$ caspase -3 signaling pathways Oncol Lett 16: 6039-6044, 2018.

45. el-Deiry WS, Harper JW, O'Connor PM, Velculescu VE, Canman CE, Jackman J, Pietenpol JA, Burrell M, Hill DE, Wang Y, et al: WAF1/CIP1 is induced in p53-mediated $\mathrm{G}_{1}$ arrest and apoptosis. Cancer Res 54: 1169-1174, 1994.

46. Giandomenico V, Vaccari G, Fiorucci G, Percario Z, Vannuchi S, Matarrese P, Malorni W, Romeo G and Affabris GR: Apoptosis and growth inhibition of squamous carcinoma cells treated with interferon-alpha, IFN-beta and retinoic acid are associated with induction of the cyclin-dependent kinase inhibitor p21. Eur Cytokine Netw 9: 619-631, 1998.

47. Miyashita T and Reed JC: Tumor suppressor p53 is a direct transcriptional activator of the human bax gene. Cell 80: 293-299, 1995.

48. Wittnebel S, Jalil A, Thiery J, DaRocha S, Viey E, Escudier B, Chouaib $S$ and Caignard $A$ : The sensitivity of renal cell carcinoma cells to interferon alpha correlates with p53-induction and involves Bax. Eur Cytokine Netw 16: 123-127, 2005.

49. Florean C, Song S, Dicato M and Diederich M: Redox biology of regulated cell death in cancer: A focus on necroptosis and ferroptosis. Free Radic Biol Med 134: 177-189, 2019

50. Peter ME, Kischkel FC, Hellbardt S, Chinnaiyan AM, Krammer PH and Dixit VM: CD95 (APO-1/Fas)-associating signalling proteins. Cell Death Differ 3: 161-170, 1996.

51. Nagata S: Apoptosis by death factor. Cell 88: 355-365, 1997.

52. Tominaga Y, Tsuzuki T, Shiraishi A, Kawate H and Sekiguchi M Alkylation-induced apoptosis of embryonic stem cells in which the gene for DNA-repair, methyltransferase, had been disrupted by gene targeting. Carcinogenesis 18: 889-896, 1997.

53. Meikrantz W, Bergom MA, Memisoglu A and Samson L: $\mathrm{O}^{6}$-alkylguanine DNA lesions trigger apoptosis. Carcinogenesis 19: 369-372, 1998.

54. Kanzawa T, Germano IM, Komata T, Ito H, Kondo $\mathrm{Y}$ and Kondo S: Role of autophagy in temozolomide-induced cytotoxicity for malignant glioma cells. Cell Death Differ 11: 448-457, 2004

55. Ling YH, Aracil M, Zou Y, Yuan Z, Lu B, Jimeno J, Cuervo AM and Perez-Soler R: PM02734 (elisidepsin) induces caspase-independent cell death associated with features of autophagy, inhibition of the Akt/mTOR signaling pathway, and activation of death-associated protein kinase. Clin Cancer Res 17: 5353-5366, 2011

56. Chen WL, Pan L, Kinghorn AD, Swanson SM and Burdette JE: Silvestrol induces early autophagy and apoptosis in human melanoma cells. BMC Cancer 167: 17, 2016.

57. Koga S, Hirohata S, Kondo Y, Komata T, Takakura M, Inoue M, Kyo S and Kondo S: A novel telomerase-specific gene therapy: Gene transfer of caspase-8 utilizing the human telomerase catalytic subunit gene promoter. Hum Gene Ther 11: 1397-1406, 2000 .

58. Hou W, Han J, Lu C, Goldstein LA and Rabinowich H: Autophagic degradation of active caspase-8: A crosstalk mechanism between autophagy and apoptosis. Autophagy 6: 891-900, 2010.

59. Sistigu A, Yamazaki T, Vacchelli E, Chaba K, Enot DP, Adam J, Vitale I, Goubar A, Baracco EE, Remédios C, et al: Cancer cell-autonomous contribution of type I interferon signaling to the efficacy of chemotherapy. Nat Med 20: 1301-1309, 2014.

60. Johns TG, Mackay IR, Callister KA, Hertzog PJ, Devenish RJ and Linnane AW: Antiproliferative potencies of interferons on melanoma cell lines and xenografts: Higher efficacy of interferon beta. J Natl Cancer Inst 84: 1185-1190, 1992.

61. Horikoshi T, Fukuzawa K, Hanada N, Ezoe K, Eguchi H, Hamaoka S, Tsujiya $\mathrm{H}$ and Tsukamoto T: In vitro comparative study of the antitumor effects of human interferon-alpha, beta and gamma on the growth and invasive potential of human melanoma cells. J Dermatol 22: 631-636, 1995.

62. Köpf J, Hanson C, Delle U, Weimarck A and Stierner U: Action of interferon alpha and beta on four human melanoma cell lines in vitro. Anticancer Res 16: 791-798, 1996. 